\title{
The Inclusion of women and young people in Brazilian Solidary Cooperatives: a proposal for an index
}

\section{La inclusión de mujeres y jóvenes en Cooperativas Brasileñas Solidarias: una propuesta para un índice}

Bruno Siqueira Fernandes - PhD Candidate in Geography (IGC/UFMG) ${ }^{1}$

Gabrielle Lima Silva - Undergraduate in International Economic Relationships (FACE/UFMG) ${ }^{2}$

Gabriel Henrique Almeida - Undergraduate in International Economic Relationships (FACE/UFMG) ${ }^{2}$

Lucas Fernandes Barbosa - Organisational Development Advisor at Trias Brazil, Minas Gerais, Brazil ${ }^{3}$

Mariana Jária Martins - Cooperativa dos Agricultores Familiares de Poço Fundo e Região Ltda (COOPFAM), Minas Gerais, Brazil ${ }^{4}$ Sibelle Cornélio Diniz - Federal University of Minas Gerais, Professor at Cedeplar/Face, Belo Horizonte, Minas Gerais, Brazil ${ }^{5}$ Thiago Neves Silva - Master student in Geography at UNIMONTES, Advisor at UNICAFES, Minas Gerais, Brazil ${ }^{6}$

1.Federal University of Minas Gerais, Research assistant at Cedeplar-Face, Belo Horizonte, Minas Gerais, Brazil, brunosiqfer@ gmail.com, https://orcid.org/0000-0002-5614-4834

2.Federal University of Minas Gerais, Undergraduate in International Economic Relationships, Belo Horizonte Minas Gerais, Brazil gabrielle.lmsv@gmail.com, https://orcid.org/oooo-0001-7887-9690; gabrielhca1@hotmail.com, https://orcid.org/oooo0003-1932-9183

3.Organisational Development Advisor at Trias Brazil, Minas Gerais, Brazil, lucasfernandes.barbosa@outlook.com,

https://orcid.org/0000-0002-7040-1622

4. Cooperativa dos Agricultores Familiares de Poço Fundo e Região Ltda (COOPFAM), Minas Gerais, Brazil, marianaj_martins@hotmail.com,https://orcid.org/o000-0003-2817-8241

5.Federal University of Minas Gerais, Professor at Cedeplar/Face, Belo Horizonte, Minas Gerais, Brazil, sibelled@cedeplar.ufmg.br; https://orcid.org/0000-0002-3183-3588

6.Federal University of Minas Gerais, Master student in Geography at UNIMONTES, Advisor at UNICAFES, Minas Gerais, Brazil, thiagoturismo@gmail.com,https://orcid.org/0000-0002-6505-4005 


\section{RESUMEN:}

Este artículo presenta la elaboración y los resultados del "Índice de Desarrollo Inclusivo para Cooperativas Solidarias" (IDICS en portugués). El Índice mide la inclusión de jóvenes y mujeres en 30 cooperativas de agricultura familiar en Minas Gerais, Brasil. Su elaboración se llevó a cabo mediante un proceso participativo con los socios y administradores de las cooperativas. IDICS consta de 2 subíndices de 18 variables cada uno: el Índice de Inclusión de Mujeres (IIM) y el Índice de Inclusión de Jóvenes (IIJ). La recolección de datos se realizó mediante cuestionarios estructurados, aplicados de forma remota a las cooperativas. Los resultados sugieren una fuerte heterogeneidad entre las cooperativas, y los resultados están relacionados con el tamaño, el tiempo de funcionamiento de la cooperativa y la región de ubicación. La mayoría de las cooperativas carecen de avances en sus procesos de inclusión. Por lo tanto, el Índice puede ser una herramienta útil para planificar e identificar buenas prácticas.

\section{ABSTRACT:}

This article presents the elaboration and the results of the "Inclusive Development Index for Solidary Cooperatives" (IDICS in Portuguese). The Index measures the inclusion of young people and women in 30 cooperatives of family farming in Minas Gerais, Brazil. Its elaboration took place through a participatory process with the cooperatives' members and managers. IDICS consists of 2 sub-indexes of 18 variables each: The Women's Inclusion Index (IIM) and the Youth Inclusion Index (IIJ). The collection of data was done through structured questionnaires, applied remotely to the cooperatives. The results suggest a strong heterogeneity among the cooperatives, and the results are related to the size, time of operation of the cooperative and the region of location. Most cooperatives lack progress with regard to their inclusion processes. Therefore, the Index can be a useful tool for planning and identifying good practices.

\section{RÉSUMÉ}

Cet article présente l'élaboration et les résultats de "l'Indice de développement inclusif pour les coopératives solidaires" (IDICS en portugais). L'Indice mesure l'inclusion des jeunes et des femmes dans 30 coopératives agricoles familiales à Minas Gerais, au Brésil. Son élaboration s'est faite dans le cadre d'un processus participatif avec les membres et les administrateurs des coopératives. IDICS se compose de deux sous-indices de 18 variables chacun : l'Indice d'inclusion des femmes (IIM) et l'Indice d'inclusion des jeunes (IIJ). La collecte des données s'est faite au moyen de questionnaires structurés, appliqués à distance aux coopératives. Les résultats suggèrent une forte hétérogénéité entre les coopératives, et les résultats sont liés à la taille, la durée de fonctionnement de la coopérative et la région d'implantation. La plupart des coopératives ne progressent pas dans leur processus d'inclusion. C'est pourquoi, l'Indice peut donc être un outil utile pour planifier et identifier les bonnes pratiques.

\section{RESUMO:}

Este artigo apresenta a elaboração e os resultados do "Índice de Desenvolvimento Inclusivo para Cooperativas Solidárias" (IDICS em português). O Índice mede a inclusão de jovens e mulheres em 30 cooperativas de agricultura familiar em Minas Gerais, Brasil. Sua elaboração foi realizada por meio de um processo participativo com os associados e administradores das cooperativas. O IDICS consiste em 2 subíndices de 18 variáveis cada: o Índice de Inclusão de Mulheres (IIM) e o Índice de Inclusão de Jovens (IIJ). A coleta de dados foi realizada por meio de questionários estruturados, aplicados remotamente às cooperativas. Os resultados sugerem uma forte heterogeneidade entre as cooperativas, e os resultados estão relacionados ao tamanho, ao tempo de funcionamento da cooperativa e à região de localização. A maioria das cooperativas carece de avanços em seus processos de inclusão. Portanto, o Índice pode ser uma ferramenta útil para planejar e identificar boas práticas.
PALABRAS CLAVES:

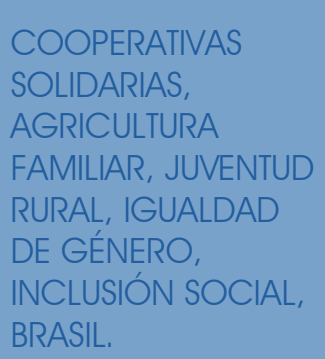

KEYWORDS:

SOLIDARITY

COOPERATIVES,

FAMILY FARMING,

RURAL YOUTH,

GENDER

EQUALITY, SOCIAL

INCLUSION,

BRAZIL.
MOTS-CLÉS:

COOPÉRATIVES

SOLIDAIRES,

AGRICULTURE

FAMILIALE,

JEUNESSE RURALE,

ÉGALITÉ DES

SEXES, INCLUSION

SOCIALE, BRÉSIL.
PALAVRAS CHAVES:

COOPERATIVAS

SOLIDÁRIAS,

AGRICULTURA FAMILIAR,

JUVENTUDE RURAL,

IGUALDADE DE GẾNERO,

INCLUSÃO SOCIAL,

BRASIL. 


\section{INTRODUCTION}

Given the contemporary context of productive restructuring, transformation and insecure jobs relations, the organization in cooperatives may be seen as a possibility of building more horizontal and solidary relations of work and production (Lima, 2004; Namorado, 2007, 2009). One of the greatest advantages of the cooperative organization is the possibility of control by the workers, which are responsible for defining the action strategies and for the technical knowledge involved in the processes (Singer, 2002; Gaiger, 2013). In this sense, cooperatives are institutions with the potential to reduce social inequalities and promote intergenerational well-being, including gender and environmental sustainability (Schneider, 2015).

Among the various topics of interest in the discussion on cooperativism, those related to gender and youth have gained importance in recent decades, especially due to the 2030 Agenda for Sustainable Development, of the United Nations. In the case of family farming and the solidarity economy, the self-perception of women about their social positions, the inclusion of women in leadership positions, the recognition of different women's jobs and the improvement in the quality of family relationships, among other topics, are discussed in recent empirical literature (Woortmann \& Woortmann, 1997; Magalhães, 2009; Simon \& Boeira, 2017; Gomes et al., 2018). The discussion on youth, on the other hand, involves intergenerational conflicts, demands for the appropriation of technologies in production and for technical and university education, among other issues (Camarano \& Abramovay, 1999; Mendonça et al., 2013; Kischener et al., 2015; Boessio \& Doula, 2016).

This article presents the process of elaboration of the "Inclusive Development Index for Solidarity Cooperatives" (IDICS), with the aim of measuring the practices of inclusion of women and youth in the 30 family farming cooperatives affiliated to the Union of Family Agriculture and Economy Cooperatives Minas Gerais Solidarity —Unicafes MG. The process of elaborating the Index was based on a collaboration between Colmeia - a group of studies, research and extension in popular and solidarity economy from Face/UFMG, Unicafes MG and Trias Brasil.

The paper was divided into five sections, in addition to this introduction. The first section provides a literature review on youth and gender in solidarity economy and family farming. The review was built from systematic bibliographic research of articles and reports produced in the last 20 years, registered with the main academicscientific indexers. The second section presents the methodology adopted for the elaboration of the Index, which included the carrying out of focus groups with members of the cooperatives and managers of Unicafes MG and methodological definitions related to the construction of the Index. The third section presents the Index proposal, while the next section presents the results. The last section brings a discussion on the suitability of IDICS to the research aims and its limits.

\section{LITERATURE REVIEW}

Even though the majority of the world's population is made up of women, and the majority of the active workforce in Brazil today is female (Simon \& Boeira, 2017), we can still observe the influence of gender discrimination in processes and labor activities. Women not only occupy fewer leadership positions than men, but they also receive lower salaries to do the same functions (Simon \& Boeira, 2017). The entry of women into the labor market, even with levels of education on average higher than men's, did not translate into fair remuneration and full guarantee of labor rights. In addition, the predominance of a view that women's activities are restricted to the domestic environment means that, even in a scenario of occupation of public spaces and outside the home, women still remain as supposedly "responsible" for domestic activities, which implies a double day of work exploration and an almost uninterrupted work period.

The organization of cooperatives, based on the principles of solidarity, equity and social emancipation, represents the possibility of creating work environments and the collectivization of production that recognize women's demands. In solidarity economy cooperatives, in several cases, women find the possibility of reconciling family and work, finding greater access to credit, alternatives for generating income and participating in professional and technical training processes (Simon \& Boeira, 2017; Guérin, 2005). In addition to generating monetary income and food security for the family, the activities allow for the development of a political sense of identity and strengthen women's struggle for recognition. 
However, the transition to a more gender-inclusive scenario within these cooperatives and associations takes longer than the principles seem to assume. As shown by Gomes et al. (2018), based on data from the Second Mapping of Solidarity Economy in Brazil (2010-2013), carried out by the now extinct National Secretariat for Solidarity Economy (SENAES), it is possible to visualize a series of bottlenecks that persist in these projects, which are connected to the typical gender oppression suffered by women in the labor market. Although cooperatives are the main source of income for women and their families, few have infrastructure focused on the specifics of the problems faced by members. As the mapping showed, only $4 \%$ of the enterprises are able to take care of the female member's children during the work period, which leaves almost $20 \%$ of the associates dependent on informal care networks (neighbors, friends and relatives) and almost $18 \%$ dependent on schools and day care centers. In addition, only $7 \%$ of husbands and partners work in domestic and care activities (Gaiger and Grupo ECOSOL, 2014 apud Simon \& Boeira, 2017).

Among production and marketing cooperatives, such as the pay or "wages" withdrawal linked to productivity still predominates $(59.1 \%)$. This form of pay, in addition to producing a work environment more susceptible to the emergence of internal hierarchies in the enterprise, can become an aggravating factor with regard to women. The frequent occurrence of double shifts, associated with care work (with children, elderly and infirm), distorts the measurement of female productivity and potentially penalizes them for not being able to dedicate themselves fully. Although only $21.1 \%$ of these cooperatives work with equal withdrawal, the very existence of a mechanism other than the one based on productivity points to a possible positive change in terms of inclusion and female socioeconomic emancipation (Gomes et al., 2018).

Another important example concerns the guarantee of labor rights safety equipment, maternity leave, professional qualification, paid rest and social security. Within the group of production and marketing cooperatives, only $17.4 \%$ ensure professional qualification and $11.8 \%$ have maternity leave. In service cooperatives, the scenario is no different: only $50 \%$ guarantee social security, with only $19.4 \%$ offering the possibility of paid rest and maternity leave (ibid).

Even in the face of these bottlenecks, the spaces created from these experiences and productive activities play a crucial role in the creation of the members' subjective and identities. For many women, the possibility of "coming to have resources under their personal control expands their decision-making power over their use, making choices different from those that the husband adopts when he has control over the family's resources" (Sales, 2009, p. 281). In addition, the work perspective based on the notions of cooperation, self-management and solidarity enables an effective participation of women in decision-making processes and in public spaces (Simon \& Boeira, 2017).

With regard to the issue of inclusion in youth, we see that young people constitute an extremely heterogeneous social group. The people that make up this group are exposed to different experiences and values, which results in a diversity of rationalizes, aspirations and desires. Despite keeping common experiences, the making of cuts is essential to understand the various youths (de Arce \& Mateo, 2018). For the perspective discussed here, that of youths in cooperativism, there is no consolidated literature, when compared to themes such as rural youth.

The socioeconomic dynamics of the countryside, say Pereira and Marcoccia (2019), is marked by a double subordination of young people and women. This condition begins in the family environment, with patriarchal repression and the centrality of the management model in the figure of the father, who is generally reluctant to accept innovations proposed by the children in management processes (Guaraná, 2009; Boessio \& Doula, 2016).

Heritage and succession strategies tend to rank the continuity of young men, resulting in the exodus of young women to medium and large cities or in migration to other communities and formation of new families in other rural communities. Allied to this, the extreme lack of material resources and public services contributes to a migration process for the urban space and contributes to the breaking of community, family and cultural ties linked to the territory left (Valadares et al., 2017). Migration ends up engendering a process of ageing and masculinization of the countryside, as well as contributing to the drop in the dynamism of the rural social fabric.

Other demands that recurrently appear in the literature on youth and cooperatives concern education and the incorporation of technological innovations in production processes (Barrios et al., 2019). Ensuring access to education and technical training proved to be one of the most effective means of maintaining the interest of young people, which points to the essential character of the partnerships established by cooperatives with teaching and educational support institutions (Boessio \& Doula, 2016). 
In addition, the result of situations where the right to participation is concentrated in the hands of a few actors, can incur in an asymmetry of power that negatively affects not only the relations within the cooperative, weakening its democratic assumptions, but also cooperative relations with markets, depending on their nature (Tamayo \& Molina, 2018). It is necessary to carry out a process of managing heterogeneity, without building rigid hierarchies that would simulate the organization of markets or capitalist companies (Tamayo \& Molina, 2018). Thus, the importance of an extraeconomic proximity between these actors becomes a central point, allowing bridges to be built between the personal lives of young people and the daily life of the cooperative. This reinforces the need for partnerships with public initiatives and policies concerned with youth, such as DAP Jovem ${ }^{1}$ and the UN Sustainable Development Goals.

Given the adverse structural conditions faced by these groups in the formal labor market, cooperativism emerges as a viable alternative by proposing a form of organization capable of providing better material, social and economic conditions for farming families, while allowing for strengthening the social fabric, interpersonal relationships and processes of identity construction and community ties.

\section{METHODOLOGY}

\section{Focus Groups}

After the literature review, focus groups were held with participants from the cooperatives and managers of Unicafes Minas Gerais. Between October $15^{\text {th }}$ and November $4^{\text {th }}, 2020,3$ focus groups were held: i) with cooperative women and managers of cooperatives; ii) with young cooperative members and managers of cooperatives; iii) with directors of Unicafes MG. The groups aimed to find the main dimensions of the inclusion of women and youth in cooperatives affiliated with Unicafes MG, from the perspective of the participants.

For each focus group, 6 to 8 participants were selected. The selection was carried out in conjunction with Unicafes MG and sought to meet the diversity of regions of the state, gender and age group. Focus groups were held in October and November 2020, through the Google Meet platform. The elaboration of the scripts, the selection of the participants and the conduction of the focus groups took place in partnership with Unicafes MG and Trias, and in line with the guidance of the bibliography specialized in qualitative methods (Bardin, 1977; Flick, 2009; Weller, 2010; Almeida, 2016). The data obtained from the focus group were analyzed using the content analysis technique, to capture patterns and categories of responses, in order to support the construction of the IDICS.

Among the main points discussed in the focus groups, we point out:

- The difficulty of attracting young people to participate in cooperatives was highlighted.

One of the participants reported that "it is necessary to rescue the meaning and importance of the work of the rural producer among young people”. Within this

- perspective, issues related to the recognition of the young person as an individual and to migration were also raised-in the focus group with women, the participants noticed the absence of young women in the countryside.

- another aspect that was often mentioned was the youth's difficulty in expressing himself. This difficulty may arise, according to the participants, from the fear of speaking up in front of parents and older members of the cooperative, or even from the lack of space for this. In contrast, the cooperatives that opened up to greater participation by this group experienced important innovations;

- as for the valorization of female work within cooperatives, there was a certain convergence in the participants' discourse regarding the difficulty of women being

- “seen". Women's work is sometimes reduced or even underestimated-even more when there are other demands that women need to meet, such as taking care of the home and family;

- according to the participating women, despite not participating so much in manual production, women are more active in marketing. When it comes time to sell products at fairs, women take on this front in cooperatives;

1 DAP is a brazilian legal instrument and certificate that allows small and familiar farmers to gain access to subsidies and credit for productive purposes. 
- life as a member has brought, for many women, greater independence, especially due to the income received. Another point mentioned that relates to the question of independence concerns mobility in the territory. According to the participants, the possession of a National Driver's License, as well as access to vehicles, are fundamental factors for the autonomy of women living in rural areas;

- the leaders acknowledged that a series of demands presented (directly or indirectly) by the young people that are not answered by the cooperatives, related to income, education, work, autonomy, credibility, among others. For them, these issues have not been well addressed within family farming cooperatives, making it difficult ("not to say impossible") to permanently attract young people to the countryside;

- For the leaders, the responsibility for the participation of young people does not fall only on the direction, but also on the cooperating youth. One of the participants spoke about the need to "create a 'enchantment' of young people with cooperativism";

- about issues related to the inclusion of women, the responses from the leaders were diverse. One of the participants stated that women do not participate due to a lack of will and initiative on their part, while another said that there is a greater dimension, involving the home and children-demands that must time and dedication;

- another participant reported that the leaders themselves sometimes do not want to give up these places or allow other people to occupy them as well. In a way, this perception converges with one of the reports presented in the second focus group: "it's not just about putting untrained women in the direction, because that would make the $30 \%$ quotas just for 'filling sausage, ${ }^{2}$ that's why the need for training and qualification" (Director of Unicafes MG, participant in the focus group, in November 2020). Other participants contributed by stating that it is not only necessary for women to change or their forced inclusion in cooperatives, but it is also necessary for men to start thinking differently about female work and the place they both occupy in the cooperative and in family life. Within this aspect, the appreciation of women's work is essential.

\section{The construction of IDICS}

The literature review and focus groups allowed us to identify the main dimensions of the inclusion of women and young people in the cooperatives in question. These dimensions were then associated with qualitative and quantitative variables. Then, a simple aggregation criterion of the variables in an Inclusive Development Index of Solidarity Cooperatives, IDICS was proposed.

The proposal for the construction of IDICS was methodologically based on the specific literature on the development of social indicators (Carley, 1985; Kayano \& Caldas, 2001; Jannuzzi, 2014, 2017) and sought to meet the following properties: i) relevance: IDICS should give for Unicafes MG and its affiliates to guide, monitor and evaluate their actions for the inclusion of young people and women; ii) validity: proximity to the abstract concept or political demand that gave rise to it (inclusion of young people and women); iii) reliability: quality of data collection, systematization and standardization; iv) good territorial and population coverage: capturing information about the reality of as many people as possible; v) sensitivity and specificity: ability to present relevant variation in the face of changes in the studied reality; vi) methodological transparency and communicability: people who did not participate in the elaboration of the index must understand its methods and objectives.

Still in accord to Kayano and Caldas (2001) and Jannuzzi (2014), and according to the previous steps, an index was chosen that was: a) goal: referring to concrete occurrences or empirical entities of social reality, constructed to from statistics; b) mixed: a composition of advice indicators, process indicators, result indicators and impact indicators (Jannuzzi, 2005); c) analytical and composite: contemplates more than one measure of the studied reality and aggregating, in a single number, several simple indicators, establishing some type of average between them.

The methodological choices mentioned above allow us to visualize two main limits of IDICS. The first limit concerns the ability to capture the reality in question. Although gender and youth issues are related to different levels of social

2 Brazilian expression that means the filling of something without purpose. In this case, the filling of the direction with women without any justification other than filling itself. 
reality (individual, family, cooperative, municipality and region, society), the focus of the Index is on the cooperative level. Thus, some issues related to the individual and the family will not be captured by IDICS. The second limit concerns the measurement of subjective aspects. Although subjective issues are crucial to capture aspects of the theme in question, IDICS does not allow them to be incorporated. We therefore suggest that subjective issues be addressed and dealt with during training and other actions within the cooperatives and Unicafes MG.

\section{IDICS: A PROPOSAL}

For the construction of IDICS, we propose two sub-indices:

1) Women's Inclusion Index (IIM)

2) Youth Inclusion Index (IIJ)

Each of the sub-indexes is made up of dimensions, which, in turn, are made up of variables. The values obtained for these variables are aggregated through a simple average (sum of the values divided by the number of variables). Then, the values referring to the dimensions are aggregated through a weighted average, considering the weights given for the dimensions (sum of multiplications between values and weights divided by the sum of weights).

The value of each sub-index varies between 0 and 1 . The closer to 0 , the lower the degree of inclusion of the cooperative to women and youth. The closer to 1, the greater the degree of inclusion.

\section{The IDICS corresponds to the simple average between the Sub-Indices and will also vary be- tween 0 and 1 , according to the degree of inclusion of the cooperative to women and youth: \\ IDICS $=(I I M+I I J) / 2$}

Annex I describe the Women's Inclusion Index (IIM) and the Youth Inclusion Index (IIJ), both composed of 3 dimensions and 18 variables. The dimensions, their respective variables and the aggregation criteria were presented and validated with the Board of Directors of Unicafes MG and the Trias team.

The first dimension concerns the "Participation and organization of women/youth in the cooperative". This dimension is considered the most relevant, as it is related to outcome variables related to inclusion in cooperatives. For this reason, this dimension was assigned a weight equal to 2 .

The second dimension refers to the "Autonomy of women/youth cooperated(s)". This dimension, although fundamental, encompasses individual variables of women and young members and, in this sense, not necessarily under the control of the cooperative. Therefore, this dimension was assigned a weight equal to 1 .

The third dimension is "Incentives for the cooperative, training and partnerships for women/youth". This dimension is related to actions at the cooperative level towards training and inclusion. This dimension was assigned a weight equal to 1.5 .

\section{RESULTS}

\section{IDICS-full version}

Of the total number of cooperatives that responded to the questionnaire (22), 12 responded to all the proposed questions. The others did not have organized information on at least one of the variables, which points to the need for greater planning by cooperatives for effective adherence to the Index, as will be discussed below. Thus, initially, the results referring to dimensions, sub-indices and IDICS for these 12 cooperatives will be presented (Table 1). 
Table 1. Descriptive statistics of dimensions, sub-indices and IDICS for 12 of the consulted cooperatives

\begin{tabular}{|c|c|c|c|c|c|}
\hline Dimension & Average & $\begin{array}{l}\text { Standard } \\
\text { Deviation }\end{array}$ & Min. & Max. & $\begin{array}{l}\text { Number of } \\
\text { Observations }\end{array}$ \\
\hline Participation and organization of women in the cooperative & 0,371 & 0,175 & 0,196 & 0,753 & 12 \\
\hline Autonomy of cooperative women & 0,627 & 0,221 & 0,280 & 1,000 & 12 \\
\hline Cooperative incentives, training and partnerships for women & 0,135 & 0,229 & 0,000 & 0,625 & 12 \\
\hline Participation and organization of youth in the cooperative & 0,273 & 0,119 & 0,050 & 0,454 & 12 \\
\hline Cooperative youth autonomy & 0,491 & 0,331 & 0,000 & 0,917 & 12 \\
\hline Cooperative incentives, training and partnerships for youth & 0,177 & 0,241 & 0,000 & 0,875 & 12 \\
\hline Women's Inclusion Index (IIM) & 0,349 & 0,126 & 0,176 & 0,595 & 12 \\
\hline Youth Inclusion Index (IIJ) & 0,289 & 0,115 & 0,022 & 0,417 & 12 \\
\hline $\begin{array}{l}\text { Inclusive Development Index for Solidarity Cooperatives } \\
\text { (IDICS) }\end{array}$ & 0,319 & 0,096 & 0,134 & 0,423 & 12 \\
\hline
\end{tabular}

Source: own elaboration based on data collected from cooperatives

As can be seen in Table 1, the dimension with the highest mean value was "Autonomy of cooperative women". This dimension also presented the highest minimum and maximum values (being the only one for which a value of " 1 " was observed for any of the cooperatives).

Then, the dimension "cooperative youth autonomy" stands out, with the second-highest average and the secondhighest maximum value. As mentioned in the previous section, these dimensions are composed of each variable of women and young cooperative members, over which cooperatives have little control.

The lowest values are related to the effective actions of the cooperatives for inclusion

(Dimensions "Incentives, training and partnerships"), both for young people and for women. This result indicates the need for greater investment by these institutions in activities involving partnerships, exchanges and training, in addition to adapting the planning and adaptation of the cooperative's space and staff.

The dimensions related to the participation and organization of women and youth had intermediate average values. Note, in this case, the smallest values of standard deviation, indicating that the realities of the cooperatives are more similar, about this dimension.

As for the sub-indices, it is observed that the highest values refer to the inclusion of women (IIM), while the IIJ has lower minimum and maximum values and lower average and standard deviation. This result is related to the better conditions of cooperative women, on average, especially in terms of participation, organization and autonomy. It should be noted, however, that the results for women and young people do not show very marked differences, which suggests the need for greater investment by cooperatives in actions for both groups.

The IDICS values had an average of 0.319 , indicating an intermediate degree of inclusion, when considering both youths and women. The low value of the standard deviation is noteworthy, which suggests that, when considering 
all dimensions of the two sub-indices, the realities of cooperatives are quite similar. This is also clear when we look at the Index's minimum and maximum values (0.134 and 0.423 , respectively).

Table 2 presents the average results for the sub-indices and for the IDICS, according to the characteristics of the cooperatives. In general, higher average values are observed (indicating a higher degree of inclusive development) in smaller cooperatives (lower volume traded, fewer members) and those with a more recent foundation (after 2006). The cooperatives in Zona da Mata and Triângulo Mineiro regions are also noteworthy.

Table 2. Average values of the sub-indices and IDICS, according to characteristics of 12 of the consulted cooperatives

\begin{tabular}{|c|c|c|c|c|}
\hline $\begin{array}{l}\text { Characteristics of the } \\
\text { cooperatives }\end{array}$ & $\begin{array}{l}\text { Women's Inclusion } \\
\text { Index (IIM) }\end{array}$ & $\begin{array}{l}\text { Youth Inclusion } \\
\text { Index (IIJ) }\end{array}$ & IDICS & $\begin{array}{c}\text { Number of } \\
\text { Observations }\end{array}$ \\
\hline $\begin{array}{c}\text { Sales volume in } 2020 \text { (tons.) } \\
2 \text { to } 5\end{array}$ & 0,546 & 0,397 & 0,472 & 2 \\
\hline 6 to 10 & 0,393 & 0,378 & 0,386 & 3 \\
\hline Over 10 & 0,291 & 0,227 & 0,259 & 6 \\
\hline $\begin{array}{l}\text { Regions } \\
\text { Jequitinhonha }\end{array}$ & 0,194 & 0,277 & 0,236 & 1 \\
\hline Metropolitana & 0,370 & 0,157 & 0,264 & 1 \\
\hline Noroeste de Minas & 0,303 & 0,220 & 0,261 & 2 \\
\hline Norte de Minas & 0,221 & 0,245 & 0,233 & 1 \\
\hline Sul/Sudoeste de Minas & - & - & - & 0 \\
\hline Triângulo Mineiro & 0,375 & 0,385 & 0,380 & 1 \\
\hline Vale do Mucuri & - & - & - & 0 \\
\hline Zona da Mata & 0,404 & 0,328 & 0,366 & 6 \\
\hline $\begin{array}{l}\text { Foundation } \\
\text { Prior to } 2005\end{array}$ & 0,233 & 0,134 & 0,183 & 2 \\
\hline 2006 to 2010 & 0,353 & 0,387 & 0,370 & 3 \\
\hline After 2010 & 0,381 & 0,292 & 0,337 & 7 \\
\hline $\begin{array}{c}\text { Number of members } \\
\text { Up to } 50\end{array}$ & 0,364 & 0,281 & 0,322 & 7 \\
\hline 51 to 150 & 0,329 & 0,302 & 0,315 & 5 \\
\hline 151 or more & - & - & - & 0 \\
\hline
\end{tabular}

Source: own elaboration based on data collected from cooperatives 


\section{IDICS-reduced version}

In view of the difficulties of a good part of the cooperatives in reporting all the information necessary to calculate the IDICS, we propose a second version of the IDICS, which we will call the "reduced version". This version is composed of the variables answered by all 22 cooperatives, which correspond to items M1, M3, M4, M6, M11 to $\mathrm{M} 18$, and $\mathrm{J} 1, \mathrm{~J} 3, \mathrm{~J} 4, \mathrm{~J} 6, \mathrm{~J} 11$ to $\mathrm{J} 18$ of the table presented in Annex I. In the reduced version, each sub-indicators are formed by 2 dimensions, totalizing 12 variables in each sub-indicator. For simplification purposes, weight 1 was assigned to each dimension. We present below the results referring to dimensions, sub-indices and the IDICS, in its reduced version, for the 22 cooperatives (Table 3).

Table 3. Descriptive statistics of dimensions, sub-indices and IDICS (reduced version) for the 22 cooperatives

\begin{tabular}{|l|c|c|c|c|c|}
\hline \multicolumn{1}{|c|}{ Dimension } & Average & $\begin{array}{c}\text { Standard } \\
\text { Deviation }\end{array}$ & Min. & Max. & $\begin{array}{c}\text { Number of } \\
\text { Observations }\end{array}$ \\
\hline $\begin{array}{l}\text { Participation and organization of women in the } \\
\text { cooperative }\end{array}$ & 0,415 & 0,191 & 0,143 & 0,880 & 22 \\
\hline $\begin{array}{l}\text { Cooperative incentives, training and partnerships for } \\
\text { women }\end{array}$ & 0,153 & 0,244 & 0,000 & 0,875 & 22 \\
\hline $\begin{array}{l}\text { Participation and organization of youth in the } \\
\text { cooperative }\end{array}$ & 0,210 & 0,166 & 0,000 & 0,576 & 22 \\
\hline $\begin{array}{l}\text { Cooperative incentives, training and partnerships for } \\
\text { youth }\end{array}$ & 0,233 & 0,262 & 0,000 & 0,875 & 22 \\
\hline Women's Inclusion Index (IIM) & 0,284 & 0,183 & 0,071 & 0,740 & 22 \\
\hline Youth Inclusion Index (IIJ) & 0,222 & 0,192 & 0,000 & 0,663 & 22 \\
\hline $\begin{array}{l}\text { Inclusive Development } \\
\text { Solidarity } \\
\text { Cooperatives (IDICS) }\end{array}$ & 0,253 & 0,173 & 0,049 & 0,702 & 22 \\
\hline
\end{tabular}

Source: own elaboration based on data collected from cooperatives

According to Table 3, the dimension with the highest average value (higher than the averages of the other dimensions) was "Participation and organization of women in the cooperative". This dimension also had the highest minimum and maximum values. Then, the dimensions linked to the IIJ are highlighted. The dimension "Incentives for the cooperative, training and partnerships for women" had the lowest average, which indicates the need for greater investment by institutions in internal discussions, exchanges and partnerships and exchanges, among other actions.

As for the sub-indices, it is observed that the highest values refer to the inclusion of women (IIM), while the IIJ has lower minimum and maximum values. This result is related to the better conditions of cooperative women, reported in the first dimension of the IIM. It should be noted, however, that the average values of the sub-indices for women and young people, as well as to being low, are very similar, which suggests the need for greater investment by cooperatives in actions for both groups. It is also observed the proximity of standard deviations and minimum and maximum values for the two sub-indices, suggesting similar realities of the inclusion of young people and women. These values are also close to those found for the IDICS, which had an average of 0.253 , indicating a low medium to intermediate degree of inclusion. 
Table 4 presents the average results for the sub-indices and for the IDICS, according to the characteristics of the cooperatives. In general, higher average values are observed in intermediate-sized cooperatives ( 2 to 5 tons sold in 2020) and with a greater number of members (more than 150). Cooperatives founded before 2005 and those in the Sul/Sudoeste de Minas, Norte de Minas, Zona da Mata and Vale do Mucuri regions stand out.

Table 4. Average values of the sub-indices and IDICS, according to characteristics of the 22 cooperatives

\begin{tabular}{|c|c|c|c|c|}
\hline Characteristics of the cooperatives & $\begin{array}{c}\text { Women's } \\
\text { Inclusion } \\
\text { Index (IIM) }\end{array}$ & $\begin{array}{c}\text { Youth } \\
\text { Inclusion } \\
\text { Index (IIJ) }\end{array}$ & IDICS & $\begin{array}{c}\text { Number of } \\
\text { Observations }\end{array}$ \\
\hline $\begin{array}{l}\text { Sales volume in } 2020 \text { (tons.) } \\
\text { Up to } 1\end{array}$ & 0,404 & 0,313 & 0,358 & 1 \\
\hline 2 to 5 & 0,593 & 0,439 & 0,516 & 2 \\
\hline 6 to 10 & 0,231 & 0,168 & 0,199 & 5 \\
\hline Over 10 & 0,272 & 0,230 & 0,251 & 11 \\
\hline $\begin{array}{l}\text { Regions } \\
\text { Jequitinhonha }\end{array}$ & 0,129 & 0,179 & 0,154 & 1 \\
\hline Metropolitana & 0,146 & 0,125 & 0,135 & 1 \\
\hline Noroeste de Minas & 0,209 & 0,136 & 0,173 & 3 \\
\hline Norte de Minas & 0,283 & 0,262 & 0,272 & 5 \\
\hline Sul/Sudoeste de Minas & 0,740 & 0,663 & 0,702 & 1 \\
\hline Triângulo Mineiro & 0,133 & 0,236 & 0,184 & 1 \\
\hline Vale do Mucuri & 0,324 & 0,002 & 0,163 & 1 \\
\hline Zona da Mata & 0,304 & 0,217 & 0,261 & 9 \\
\hline $\begin{array}{l}\text { Foundation } \\
\text { Prior to } 2005\end{array}$ & 0,380 & 0,291 & 0,335 & 5 \\
\hline 2006 to 2010 & 0,305 & 0,205 & 0,255 & 7 \\
\hline After 2011 & 0,222 & 0,199 & 0,210 & 10 \\
\hline $\begin{array}{l}\text { Number of members } \\
\text { Up to } 50\end{array}$ & 0,226 & 0,164 & 0,195 & 9 \\
\hline 51 to 150 & 0,271 & 0,175 & 0,223 & 9 \\
\hline 151 or more & 0,444 & 0,456 & 0,450 & 4 \\
\hline
\end{tabular}

Source: own elaboration based on data collected from cooperatives 


\section{FINAL CONSIDERATIONS}

This article sought to present the process of elaboration of the Inclusive Development Index for Solidarity Cooperatives (IDICS), with the aim of measuring the practices of inclusion of women and youth in the 30 family farming cooperatives affiliated to Unicafes MG. The process of building the Index went through document analysis, literature review and focus groups with members of cooperatives and managers of Unicafes MG. These steps allowed the identification of three dimensions of inclusion of women and youth in the cooperatives in question: i) participation and organization; ii) autonomy; iii) incentives for the cooperative, training and partnerships. These dimensions were then associated with numerical variables. Then, a simple aggregation criterion for the variables into two sub-indices was proposed: The Women's Inclusion Index (IIM) and the Youth Inclusion Index (IIJ). IDICS corresponds to the simple average of these two indicators.

More than just a number or an indicator, the Index can be seen as a collective construction, expressing in each dimension and in each variable an active demand of representatives and cooperative members of Unicafes MG on topics related to inclusion. The IDICS tool represents the possibility of periodic monitoring, by cooperatives and Unicafes MG, of their progress with regard to the inclusion of young people and women. For this, it is necessary that the data are periodically updated by the cooperatives, since the construction of a historical series for the Index, with defined periodicity, can give to a better monitoring of the inclusive development of the cooperatives. To this end, cooperatives must have a data collection plan, such as establishing their own schedule that meets the institution's specificities and including data collection in the agenda for assemblies and meetings.

Some tools can give to the effective adhesion to IDICS by cooperatives and Unicafes MG, as well as to the introduction and consolidation of the discussions and debates raised during the elaboration of the Index in the daily routine of the management processes of the cooperatives. Among these tools, we highlight a possible advertising material for IDICS, intended for its dissemination to cooperatives and members, seeking to give greater visibility to the Index.

Another possible tool is a spreadsheet, which cooperatives can use for their own diagnosis and planning of actions. It is important that a cooperative member become responsible for collecting and organizing the information that composes the dimensions of the Index to feed this spreadsheet with new information and data. The person chosen should preferably be on the cooperative's board of directors and have knowledge on the topic of inclusion of young people and women, in addition to having ample access to all the required information.

As possible consequences of post-pandemic action, we suggest the exchange of experiences between cooperatives, focusing on those that stand out for their inclusion activities. In addition, the holding of courses, lectures and training on these topics is extremely important for the continuity of debates around inclusion and for raising the awareness of cooperative members and managers about the importance of data collection and its incorporation into planning activities. 


\section{REFERENCES}

Almeida, R. (2016). Roteiro para o emprego de grupos focais. In Métodos de pesquisa em Ciências Sociais: Bloco Qualitativo (1.st ed.) (p. 42-59). Sesc São Paulo/CEBRAP.

Barrios, C. L., Lomelí, C. Z., Villar, S. C. \& Fernández, L. P. (2019). Campesinos a contracorriente. Estrategias organizativas, productivas y comerciales de la cooperativa indígena campesina Maya Vinic. Región y sociedad, 31.

Boessio, A. T. \& Doula, S. M. (2016). Jovens rurais e influências institucionais para a permanência no campo: um estudo de caso em uma cooperativa agropecuária do Triângulo Mineiro. Interações, 17(3), 370-383.

Camarano, A. A. \& Abramovay, R. (1999). Êxodo Rural, envelhecimento e masculinização no Brasil: Panorama dos últimos 50 anos [texto para Discussão n.o 621]. IPEA. https://www.ipea.gov.br/portal/index.php?option=com_ content\&view=article\&id=3929.

Carley, M. (1985). Indicadores sociais: teoria e prática. Zahar.

de Arce, A. \& Mateo, G. (2018). Juventudes, arraigo y pervivencia del cooperativismo agrario Agricultores Federados Argentinos, 1998-2016. Pilquen, 21(5), 49-62.

Flick, U. (2009). Introdução à Pesquisa Qualitativa (3.rd ed.). Artmed.

Gaiger, L. I. (2013). A economia solidária e a revitalização do paradigma cooperativo. Revista Brasileira de Ciências Sociais, 28(82), 211-228.

Gomes, E., Silva, F. \& Pereira, E. M. (2018). Um olhar sobre o trabalho em cooperativas da economia solidária e a intersecção com as questões de gênero e raça. Revista de Extensão e Estudos Rurais, 7(1), 94-1 17.

Guaraná, E. (2009). Juventude rural no Brasil: processos de exclusão e a construção de um ator político. Revista Latinoamericana de Ciencias Sociales Niñez y Juventud, 7(1).

Jannuzzi, P. M. (2014). Indicadores para diagnóstico, monitoramento e avaliação de programas sociais no Brasil. Revista do Serviço Público, 56(2), 137-160. https://doi.org/10.21874/rsp.v56i2.222.

Jannuzzi, P. M. (2017). Indicadores Sociais no Brasil: conceitos, fontes de dados e aplicações (6.th ed.). Alínea.

Kayano, J. \& Caldas, E. L. (2001). Indicadores para o diálogo. Programa Gestão Pública e Cidadania. EAESP/FGV.

Kischener, M., Kiyota, N. \& Perondi, M. (2015). Sucessão geracional na agricultura familiar: lições apreendidas em duas comunidades rurais. Mundo Agrário, $16(33)$.

Lima, J. C. (2004). O trabalho autogestionário em cooperativas de produção: o paradigma revisitado. Revista Brasileira de Ciências Sociais, 19(56), p. 45-62.

Magalhães, R. S. (2009). A “masculinização” da produção de leite. Revista de Economia e Sociologia Rural, 47(1), $275-299$.

Mendonça, K. F. B., Magalhães, E., Galizoni, F. \& Anjos, H. (2013). Formação, sucessão e migração: trajetórias de duas gerações de agricultores do Alto Jequitinhonha, Minas Gerais. Revista Brasileira de Estudos Populacionais, 30(2), 445-463.

Namorado, R. (2007). Cooperativismo - história e horizontes. In J. Gediel (org.), Estudos de Direito Cooperativo e Cidadania. Programa de Pós-Graduação em Direito da UFPR.

Namorado, R. (2009). Cooperativismo. In A. D. Cattani, J. L. Laville \& P. Hespahna (eds.), Dicionário internacional da Outra Economia. Almedina/CES.

Pereira, M. \& Marcoccia, P. (2019). Subalternização no trabalho e na educação de jovens da agricultura familiar no Primeiro e Segundo Planalto do município da Lapa/Paraná: possibilidades de superação. Revista Brasileira de Educação, 24, e240022.

Schneider, J. O. (2015). Cooperativismo e desenvolvimento sustentável. Otra Economía, 9(16), 94-104.

Simon, V. P. \& Boeira, S. L. (2017). Economia social e solidária e empoderamento feminino. Ciências Sociais Unisinos, 53(3), 532-542.

Singer, P. (2002). Introdução à Economia Solidária. Editora Fundação Perseu Abramo. 
Tamayo, P. A. \& Molina, N. (2018). Acción colectiva y asociación de heterogeneidades en mercados agroecológicos campesinos: Asoproorgánicos (Cali, Colombia). Revista Colombiana de Sociología, 41(2), 83-101.

Valadares, A. A., Ferreira, B., Martins, L. \& Galiza, M. (2017). A juventude rural no III Festival da Juventude da Contag: relatório de pesquisa. IPEA.

Woortmann, E. F. \& Woortmann, K. (1997). O Trabalho da Terra: a lógica e a simbólica da lavoura camponesa. Editora Universidade de Brasília. 
Annex I - Description of the IDICS component sub-indices - full version

Table I.1. Description of the Women's Inclusion Index (IIM)-dimensions and variables

\begin{tabular}{|c|c|c|}
\hline \multicolumn{3}{|c|}{ DIMENSION: WOMEN'S PARTICIPATION AND ORGANIZATION IN COOPERATIVE (weight = 2) } \\
\hline Variable & Calculation method & Nature of variable \\
\hline $\begin{array}{l}\text { M1. Female participation in the } \\
\text { cooperative (cooperated) }\end{array}$ & Number of women members/Total number of members & $\begin{array}{l}\text { Proportion (varies between } 0 \\
\text { and 1) }\end{array}$ \\
\hline $\begin{array}{l}\text { M2. Female participation in the } \\
\text { cooperative (employees) }\end{array}$ & $\begin{array}{l}\text { Number of female employees in the cooperative/Total number of } \\
\text { employees in the cooperative }\end{array}$ & $\begin{array}{l}\text { Proportion (varies between } 0 \\
\text { and 1) }\end{array}$ \\
\hline $\begin{array}{l}\text { M3. Participation of women in } \\
\text { management positions }\end{array}$ & $\begin{array}{l}\text { Number of women in management positions in the cooperative/Total } \\
\text { number of people in management positions in the cooperative }\end{array}$ & $\begin{array}{l}\text { Proportion (varies between } 0 \\
\text { and 1) }\end{array}$ \\
\hline $\begin{array}{l}\text { M4. Participation of women in } \\
\text { commercialization }\end{array}$ & $\begin{array}{l}\text { Number of women members who participate in commercialization in } \\
\text { the last } 2 \text { years/Total number of women members }\end{array}$ & $\begin{array}{l}\text { Proportion (varies between } 0 \\
\text { and 1) }\end{array}$ \\
\hline $\begin{array}{l}\text { M5. Female participation in } \\
\text { assemblies }\end{array}$ & $\begin{array}{l}\text { Number of women who attended the last cooperative meeting/Total } \\
\text { number of cooperative women }\end{array}$ & $\begin{array}{l}\text { Proportion (varies between } 0 \\
\text { and 1) }\end{array}$ \\
\hline $\begin{array}{l}\text { M6. Existence of a women's group } \\
\text { or collective }\end{array}$ & $\begin{array}{l}\text { Existence of a work group or collective formed by women in the } \\
\text { cooperative }\end{array}$ & Binary $($ Yes $=1 ; \mathrm{No}=0)$ \\
\hline \multicolumn{3}{|c|}{ DIMENSION: AUTONOMY OF COOPERATED WOMEN (weight = 1) } \\
\hline Variable & Calculation method & Nature of variable \\
\hline M7. Education & $\begin{array}{l}\text { Number of cooperative women with complete secondary education, } \\
\text { complete higher education or technical education/Total number of } \\
\text { cooperative women }\end{array}$ & $\begin{array}{l}\text { Proportion (varies between } 0 \\
\text { and 1) }\end{array}$ \\
\hline M8. Income & $\begin{array}{l}\text { Average commercial participation (income) of cooperative women/ } \\
\text { Total average commercial participation (income) }\end{array}$ & $\begin{array}{l}\text { Proportion (varies between } 0 \text { and } \\
1 \text { ) * }\end{array}$ \\
\hline M9. Autonomy related to mobility & $\begin{array}{l}\text { Number of female members who have a National Driver's License/ } \\
\text { Total number of female members }\end{array}$ & $\begin{array}{l}\text { Proportion (varies between } 0 \\
\text { and 1) }\end{array}$ \\
\hline $\begin{array}{l}\text { M10. Autonomy related } \\
\text { to credit and participation } \\
\text { in technical/productive } \\
\text { assistance programs }\end{array}$ & $\begin{array}{l}\text { Number of cooperative women whose names } \\
\text { appear in the DAP/Total number of cooperative } \\
\text { women }\end{array}$ & $\begin{array}{l}\text { Proportion (varies } \\
\text { between } 0 \text { and } 1 \text { ) }\end{array}$ \\
\hline
\end{tabular}


DIMENSION: INCENTIVES FOR THE COOPERATIVE, TRAINING AND PARTNERSHIPS (weight $=1,5$ )

\begin{tabular}{|c|c|c|}
\hline Variable & Calculation method & Nature of variable \\
\hline $\begin{array}{l}\text { M11. Existence of a "quota" for } \\
\text { women (percentage or minimum } \\
\text { number of cooperative women) }\end{array}$ & $\begin{array}{l}\text { Existence of a percentage or minimum number of participations of } \\
\text { cooperative women }\end{array}$ & Binary $($ Yes $=1 ; \mathrm{No}=0)$ \\
\hline $\begin{array}{l}\text { M12. Existence of space or activities } \\
\text { for children in the cooperative }\end{array}$ & $\begin{array}{l}\text { Does the cooperative have a space for children under the care of the } \\
\text { cooperative members, during the meetings and events held by the } \\
\text { cooperative? Or does the cooperative have someone responsible for } \\
\text { taking care of these children during the events? }\end{array}$ & Binary $($ Yes $=1 ; \mathrm{No}=0)$ \\
\hline $\begin{array}{l}\text { M13. Existence of a resolution or } \\
\text { plan related to gender } \\
\text { equality }\end{array}$ & $\begin{array}{l}\text { Existence, in the statute or plan of the cooperative, of a resolution } \\
\text { aimed at promoting, reinforcing and monitoring equality and non- } \\
\text { discrimination based on sex }\end{array}$ & Binary $($ Yes $=1 ; \mathrm{No}=0)$ \\
\hline $\begin{array}{l}\text { M14. Internal training/education on } \\
\text { the gender theme }\end{array}$ & $\begin{array}{l}\text { In the last } 2 \text { years, has there been any training (course, lecture...) on } \\
\text { the topic of gender, organized by the cooperative itself? }\end{array}$ & Binary $($ Yes $=1 ; \mathrm{No}=0)$ \\
\hline $\begin{array}{l}\text { M15. Existence of a sector or } \\
\text { employee dedicated to issues related } \\
\text { to women }\end{array}$ & $\begin{array}{l}\text { Existence of a sector or employee dedicated to issues related to } \\
\text { women }\end{array}$ & Binary $($ Yes $=1 ; \mathrm{No}=0$ ) \\
\hline M16. Partnership with institutions & $\begin{array}{l}\text { In addition to Unicafes } M G \text {, does the cooperative have a partnership } \\
\text { with any institution for the development of specific actions for women? }\end{array}$ & Binary $($ Yes $=1 ; \mathrm{No}=0)$ \\
\hline $\begin{array}{l}\text { M17. Exchange with other } \\
\text { cooperatives and institutions }\end{array}$ & $\begin{array}{l}\text { Has the cooperative already promoted any exchanges with other } \\
\text { cooperatives or other successful institutions in the inclusion of women } \\
\text { (with the exception of Unicafes } M G \text { )? }\end{array}$ & Binary $(\mathrm{Yes}=1 ; \mathrm{No}=0$ ) \\
\hline $\begin{array}{l}\text { M18. Existence of an income } \\
\text { generation project aimed at women }\end{array}$ & $\begin{array}{l}\text { Does the cooperative have any job and income generation project } \\
\text { specifically for women? }\end{array}$ & Binary $(\mathrm{Yes}=1 ; \mathrm{No}=0)$ \\
\hline
\end{tabular}

\section{Source: own elaboration.}

* For this variable, there is the possibility of values greater than 1. In these cases, the maximum value of the variable will be set to 1 , for simplification purposes. 


\section{Table I.2. Description of the Youth Inclusion Index (IIJ)-dimensions and variables}

\begin{tabular}{|c|c|c|}
\hline \multicolumn{3}{|c|}{ DIMENSÃO: PARTICIPAÇÃO E ORGANIZAÇÃO DE JOVENS NA COOPERATIVA (weight = 2) } \\
\hline Variable & Calculation method & Nature of variable \\
\hline $\begin{array}{l}\text { J1. Participation of young people in } \\
\text { the cooperative (cooperatives) }\end{array}$ & Number of young members/Total number of members & $\begin{array}{l}\text { Proportion (varies between } 0 \\
\text { and 1) }\end{array}$ \\
\hline $\begin{array}{l}\text { J2. Participation of young people in } \\
\text { the cooperative (employees) }\end{array}$ & $\begin{array}{l}\text { Number of young employees in the cooperative/Total number of } \\
\text { employees in the cooperative }\end{array}$ & $\begin{array}{l}\text { Proportion (varies between } 0 \\
\text { and 1) }\end{array}$ \\
\hline $\begin{array}{l}\text { J3. Participation of young people in } \\
\text { management positions }\end{array}$ & $\begin{array}{l}\text { Number of young people in management positions in the cooperative/ } \\
\text { Total number of people in management positions in the cooperative }\end{array}$ & $\begin{array}{l}\text { Proportion (varies between } 0 \\
\text { and 1) }\end{array}$ \\
\hline $\begin{array}{l}\text { J4. Participation of young people in } \\
\text { commercialization }\end{array}$ & $\begin{array}{l}\text { Number of young members who participate in commercialization in } \\
\text { the last } 2 \text { years/Total number of young members }\end{array}$ & $\begin{array}{l}\text { Proportion (varies between } 0 \\
\text { and 1) }\end{array}$ \\
\hline $\begin{array}{l}\text { J5. Participation of young people in } \\
\text { assemblies }\end{array}$ & $\begin{array}{l}\text { Number of young people who attended the last cooperative meeting/ } \\
\text { Total number of young members }\end{array}$ & $\begin{array}{l}\text { Proportion (varies between } 0 \\
\text { and 1) }\end{array}$ \\
\hline $\begin{array}{l}\text { J6. Existence of a youth group or } \\
\text { collective }\end{array}$ & $\begin{array}{l}\text { Existence of a work group or collective formed by young people in the } \\
\text { cooperative }\end{array}$ & Binary $\left(\right.$ Yes $\left.=1 ; \mathrm{No}_{0}=0\right)$ \\
\hline \multicolumn{3}{|c|}{ DIMENSÃO: AUTONOMIA DA JUVENTUDE COOPERADA (weight = 1) } \\
\hline Variable & Calculation method & Nature of variable \\
\hline J7. Education & $\begin{array}{l}\text { Number of cooperative youth with complete secondary education, } \\
\text { complete higher education or technical education/Total number of } \\
\text { cooperative youth }\end{array}$ & $\begin{array}{l}\text { Proportion (varies between } 0 \\
\text { and 1) }\end{array}$ \\
\hline J8. Income & $\begin{array}{l}\text { Commercial participation (income) average of young cooperative } \\
\text { members/Commercial participation (income) average total }\end{array}$ & $\begin{array}{l}\text { Proportion (varies between } 0 \text { and } \\
1 \text { ) * }\end{array}$ \\
\hline $\begin{array}{l}\text { 19. Autonomy related to land } \\
\text { ownership }\end{array}$ & $\begin{array}{l}\text { Number of cooperative youth whose names appear on the land title/ } \\
\text { Total number of cooperative youth }\end{array}$ & $\begin{array}{l}\text { Proportion (varies between } 0 \\
\text { and 1) }\end{array}$ \\
\hline
\end{tabular}


J10. Autonomy related to credit and participation in technical/ productive assistance programs
Number of cooperative youth whose names appear in the DAP (DAP

Jovem)/Total number of cooperative youth
Proportion (varies between 0 and 1)

\section{DIMENSÃO: INCENTIVOS PELA COOPERATIVA, FORMAÇÃO E PARCERIAS (weight = 1,5)}

\begin{tabular}{|c|c|c|}
\hline Variable & Calculation method & Nature of variable \\
\hline $\begin{array}{l}\text { J11. Existence of a "quota" for } \\
\text { young people (percentage or } \\
\text { minimum number of cooperative } \\
\text { young people) }\end{array}$ & $\begin{array}{l}\text { Existence of a percentage or minimum number of cooperative youth } \\
\text { participation }\end{array}$ & Binary $(\mathrm{Yes}=1 ; \mathrm{No}=0)$ \\
\hline $\begin{array}{l}\mathrm{J} 12 \text {. Existence of resolution or plan } \\
\text { related to youth }\end{array}$ & $\begin{array}{l}\text { Existence, in the statute or plan of the cooperative, of a resolution } \\
\text { aimed at promoting, reinforcing and monitoring the inclusion of young } \\
\text { people and the right to education of young people }\end{array}$ & Binary $(\mathrm{Yes}=1 ; \mathrm{No}=0)$ \\
\hline $\begin{array}{l}\text { J13. Internal training on the topic } \\
\text { of youth }\end{array}$ & $\begin{array}{l}\text { In the last } 2 \text { years, has there been any training (course, lecture...) on } \\
\text { the topic of youth, organized by the cooperative itself? }\end{array}$ & Binary $($ Yes $=1 ; \mathrm{No}=0)$ \\
\hline $\begin{array}{l}\text { J14. Existence of a sector or } \\
\text { employee dedicated to issues related } \\
\text { to youth }\end{array}$ & Existence of a sector or employee dedicated to issues related to youth & Binary $($ Yes $=1 ; \mathrm{No}=0)$ \\
\hline J15. Partnership with institutions & $\begin{array}{l}\text { In addition to Unicafes MG, does the cooperative have a partnership } \\
\text { with any institution for the development of specific actions for young } \\
\text { people? }\end{array}$ & Binary $($ Yes $=1 ; \mathrm{No}=0)$ \\
\hline $\begin{array}{l}\text { J16. Exchange with other } \\
\text { cooperatives and institutions }\end{array}$ & $\begin{array}{l}\text { Has the cooperative already promoted any exchanges with other } \\
\text { cooperatives or other successful institutions in the inclusion of young } \\
\text { people (with the exception of Unicafes MG)? }\end{array}$ & Binary $($ Yes $=1 ; \mathrm{No}=0)$ \\
\hline $\begin{array}{l}\text { J17. Existence of a project related } \\
\text { to technological incorporation or } \\
\text { innovation }\end{array}$ & $\begin{array}{l}\text { Are there projects for technological incorporation or product } \\
\text { innovation in the cooperative? }\end{array}$ & Binary $(Y e s=1 ; \mathrm{No}=0)$ \\
\hline $\begin{array}{l}\text { J18. Existence of an income } \\
\text { generation project aimed at young } \\
\text { people }\end{array}$ & $\begin{array}{l}\text { Does the cooperative have any job and income generation project } \\
\text { specifically for young people? }\end{array}$ & Binary $($ Yes $=1 ; \mathrm{No}=0)$ \\
\hline
\end{tabular}

Source: own elaboration.

* For this variable, there is the possibility of values greater than 1. In these cases, the maximum value of the variable will be set to 1 , for simplification purposes. 